\title{
Drug Therapy Monitoring in Patients with Type 2 Diabetes and Hypertension
}

\author{
José Francisco Castro Bolívar ${ }^{1}$, Fernando Martínez-Martínez ${ }^{2}$ and Mónica Ferrit-Martin ${ }^{3}$ \\ 1. Faculty of Chemistry and Pharmacy, Universidad del Atlántico, Hospital Pharmacy and Pharmacology Research Group (GIFAF), \\ Barranquilla 08003, Colombia \\ 2. Pharmaceutical Care Research Group, Universidad de Granada, Granada 18010, Spain \\ 3. Pharmacy Department, Virgen de las Nieves Universitario Hospital, Granada 18014, Spain
}

\begin{abstract}
The aim of this paper is to detect, prevent and resolve DRP (drug-related problems) and NOM (negative outcomes associated with medication) in hospitalized patients with DM2 (type 2 diabetes) with HTN (hypertension) in a tertiary care clinic. Descriptive cross-sectional interventional study is used. DTM (drug therapy monitoring) was conducted in 73 patients using data obtained from clinical histories and interviews. NOM were detected based on symptoms and laboratory test results. The statistical significance was 0.05 . It can be found that 23 DRP were detected, primarily in the category "likelihood of adverse effects" (30.43\%) causing NOM in the "non-quantitative safety problem" category. The NOM detected were related to safety $(62 \%)$, effectiveness $(24.5 \%)$ and necessity (13.5\%). Of the $68.57 \%$ of pharmacist interventions accepted, $48.57 \%$ were resolved and $20 \%$ were not resolved. A simple linear correlation $(r=-0.34)$ analysis indicated a weak association between patient age and severity of NOM. DTM made it possible to detect suspected DRP and NOM, which were then prevented or resolved, improving the control of HTN and DM2 and helping ensure better drug therapy outcomes for patients.
\end{abstract}

Key words: Drug therapy monitoring, type 2 diabetes mellitus, hypertension, pharmacist intervention.

\section{Introduction}

Diabetes is a very common metabolic disorder, an extremely serious disease and major cause of disability and death. Pharmacists play a key role in DTM (drug therapy monitoring) by detecting, preventing and resolving NOM (negative outcomes associated with medication). The Dader method is a key tool in this process [1]. Once DRP (drug-related problems) and NOM have been detected, pharmacists conduct the interventions necessary to resolve them and then evaluate the outcome [2].

According to the WHO (World Health Organization), more than 220 million people worldwide had diabetes in 2010 (a 46\% increase since 2000), and it is estimated that this will increase to 300 million by 2025 [3].

The global prevalence of diabetes among adults over

Corresponding author: José Francisco Castro Bolívar, MSc. research fields: drug therapy monitoring, pharmacovigilance, drug utilization studies and health education.
18 years of age was $9 \%$ in 2014 [4]. In 2012, an estimated 1.5 million deaths were directly caused by DM2 (type 2 diabetes) [5]. More than $80 \%$ of DM2 deaths occur in low and middle-income countries. WHO projects that diabetes will be the seventh leading cause of death in 2030 [6]. A healthy diet, regular physical activity, maintaining a healthy body weight and avoiding tobacco use can prevent or delay DM2 onset [7].

DM2 is the most common form of diabetes, representing $80 \sim 90 \%$ of cases, and a serious health problem in both developed and developing countries [8]. Most cases of DM2 occur in the context of metabolic syndrome, a combination of DM2, HTN (hypertension), elevated cholesterol, triglycerides and/or uric acid, and obesity [8].

In addition to its high prevalence, DM2 is responsible for high morbidity and mortality rates. The associated cost of the disease is also high, primarily 
because of its chronic complications. There is also a high incidence of DM2-related NOM. The total cost of those NOM can be as high as 177.4 billion dollars per year [9].

According to Orozco [10], approximately a quarter of the world population is hypertensive and the prevalence of DM2 in the adult population is around $6 \sim 8 \%$.

Pharmacists are drug experts with the opportunity to see chronic patients five times as frequently as other health professionals. Because of this higher degree of accessibility, they can be valuable members of multidisciplinary teams responsible for the care of chronic patients [11].

Pharmaceutical care, specifically DTM (where pharmacists are responsible for patients' drug-related needs), could help deliver better health outcomes for DM2 patients with HTN through the detection, prevention and resolution of NOM [12].

In light of all the above, tertiary care clinics are now focusing their efforts on reducing the impact of these complex diseases. A proposal was, therefore, made to implement a DTM service for patients with DM2 and HTN. The primary aim of this study was to detect, prevent and resolve DRP and NOM in hospitalized patients with DM2 and HTN in a tertiary care clinic using the Dader method.

\section{Methods}

This descriptive interventional cross-sectional prospective study was conducted between November 2012 and January 2013 in a tertiary care clinic in Barranquilla, Colombia. A simple randomized method was used to draw a sample from a population of patients diagnosed with DM2 with HTN. For an accuracy of $5 \%$ and confidence level of $95 \%$, a sample of 73 patients was required. Hospitalized patients of both sexes aged 18 or over with the required diagnosis were asked to participate and those who agreed signed an informed consent. The Dader method of drug therapy monitoring defined by the Third Consensus of
Granada was used [13]. A simple randomized sample was drawn from patients who met the inclusion criteria. The study was conducted in accordance with the guidelines set out in the Declaration of Helsinki [14].

The first stage of the study consisted of talking to the participants, providing a clear, precise and concise explanation of the study aim and duration and how much time each participant would need to devote to the study. The study participants were also given details of the study procedures and it was stressed that they were free to continue or withdraw from the study whenever they deemed appropriate, and that the information obtained would be kept confidential. Finally, the participants were told that they would need to sign an informed consent form as a means to protect their rights as patients.

Data were obtained and measured in the following stages:

(1) Stage I: detect DRP and NOM in patients treated for DM2 with HTN: the clinical histories of patients diagnosed with both conditions, based on clinical laboratory results (blood sugar levels) and measurements (blood pressure), were reviewed. Patients were interviewed to collect data on signs, symptoms and prescribed medications;

(2) Stage II: determine the number of drugs linked to the appearance of DRP and NOM: each patient's current health status was determined. If the presence of a NOM was confirmed, the drug involved was identified. In this way, the prescribed medications responsible for NOM could be determined;

(3) Stage III: evaluate the acceptance rate of pharmacist interventions and degree of resolution of NOM: once the NOM were detected, the pharmacist intervention was sent in writing to the healthcare team (doctor/nurse/patient) who decided whether or not to accept it. Patient follow-up was then conducted to determine if the intervention was accepted and whether or not the health problem was resolved [15].

In cases of non-quantitative safety problems, the 
algorithm defined by Naranjo et al. [15] was used to determine whether or not the adverse reactions could be attributed to the drugs [16].

Once NOM were detected, pharmacist interventions were conducted to resolve or prevent health problems in the patients. The interventions were divided into two categories:

(1) pharmacist-patient interventions;

(2) pharmacist-patient-doctor interventions.

The tools used to gather data were those validated by the Pharmaceutical Care Research Group of the University of Granada, Spain, which have been used to conduct drug therapy monitoring studies internationally.

The Student's $t$-test was used to compare means of the quantitative variables (age, average hospital stay, duration of monitoring, use of drugs). For normally distributed variables, the Chi-square test was used to perform non-parametric tests (sex, age, etc.).

\section{Results}

The 73 patients were interviewed $(54.8 \%$ male, $45.2 \%$ female). $68.5 \%$ of participants were over 60 years of age, and $24.66 \%$ were between 45 and 59 . The most prevalent diagnosis was HTN (59\%), followed by DM2 with HTN (36\%) and DM2 only (5\%) (Table 1).

Table 2 shows that the most frequent DRP were in the "likelihood of adverse effects" (32.43\%), "non-adherence" (16.22\%) and "personal characteristics" (13.51\%) categories. More NOM were detected among males $(64.87 \%)$ than females $(35.13 \%)$. The NOM identified most frequently were non-quantitative safety problems (62\%), followed by NOM related to necessity (untreated health problems $(13.5 \%))$ and quantitative ineffectiveness (13.5\%), and finally non-quantitative ineffectiveness (11\%). With regard to the severity of safety-related NOM, $30.43 \%$ were moderate in both men and women and $21.74 \%$ were severe in men (Table 3 ).

Table 4 shows the number of drugs administered to 29 of the 73 patients in the study who had NOM, with 3 patients who had been prescribed 11 drugs. The therapeutic groups affected by the drugs were the alimentary tract and metabolism, and blood and blood forming organs, both with $30 \%$.

Table 5 shows the drugs involved in the appearance of NOM, including losartan (27\%) followed by furosemide (19\%). The most frequent NOM were non-quantitative safety problems $(62.16 \%)$, followed by quantitative ineffectiveness and untreated health problems (both 13.5\%).

Table 6 shows the outcomes of the pharmacist interventions. 35 pharmacist interventions were conducted as a result of the suspected DRP and NOM detected. $68.57 \%$ were accepted and $31.43 \%$ were not accepted.

Table 1 Sex, age and clinical diagnosis of patients included in the drug therapy monitoring trial.

\begin{tabular}{|c|c|c|c|c|c|c|c|}
\hline \multirow{3}{*}{ Items } & & & \multicolumn{4}{|c|}{ Sex } & \multirow[t]{2}{*}{ Total } \\
\hline & & & \multicolumn{2}{|l|}{ Male } & \multicolumn{2}{|l|}{ Female } & \\
\hline & & & Number & Percentage $(\%)$ & Number & Percen & \\
\hline \multicolumn{2}{|c|}{ Sample size } & 73 & 40 & 54.8 & 33 & 45.20 & 100 \\
\hline \multirow{5}{*}{ Age } & Age (years) mea & & $63.3 \pm 13$ & & $69.66 \pm 1$ & & \\
\hline & $\geq 60$ years & 50 & 26 & 35.62 & 24 & 32.88 & 68.5 \\
\hline & $45 \sim 59$ years & 18 & 11 & 15.07 & 7 & 9.59 & 24.66 \\
\hline & 25 44 years & 5 & 3 & 4.11 & 2 & 2.74 & 6.85 \\
\hline & Total & 73 & 40 & 54.8 & 33 & 45.20 & 100 \\
\hline \multirow{3}{*}{$\begin{array}{l}\text { Clinical } \\
\text { diagnosis }\end{array}$} & HTN & & I10 & & & 43 & 59 \\
\hline & DM2 and HTN & & E11/I10 & & & 26 & 36 \\
\hline & DM2 & & E11 & & & 4 & 5 \\
\hline
\end{tabular}

Source: data obtained from the initial interview and clinical histories. 
Table 2 Types of DRP (drug-related problems) and NOM (negative outcomes associated with medication) by sex y category.

\begin{tabular}{|c|c|c|c|c|c|}
\hline \multicolumn{2}{|l|}{ Types of DRP } & Men & Women & Total & Percentage $(\%)$ \\
\hline \multicolumn{2}{|c|}{ Likelihood of adverse effects } & 7 & 5 & 12 & 32.43 \\
\hline \multicolumn{2}{|c|}{ Non-adherence } & 6 & 0 & 6 & 16.22 \\
\hline \multicolumn{2}{|c|}{ Personal characteristics } & 4 & 1 & 5 & 13.51 \\
\hline \multicolumn{2}{|c|}{ Insufficiently treated health problem } & 3 & 2 & 5 & 13.51 \\
\hline \multicolumn{2}{|c|}{ Inappropriate dose, dosage regimen and/or duration } & 1 & 3 & 4 & 10.81 \\
\hline \multicolumn{2}{|c|}{ Interactions } & 1 & 2 & 3 & 8.11 \\
\hline \multicolumn{2}{|c|}{ Incorrect administration of the drug } & 1 & 1 & 2 & 5.41 \\
\hline \multicolumn{2}{|c|}{ Total } & 23 & 14 & 37 & 100 \\
\hline Sex & \multicolumn{2}{|c|}{ Patients with NOM $(n=28)$} & No. of NOM $(n=9)$ & \multicolumn{2}{|c|}{ Total NOM $n=37(\%)$} \\
\hline \multirow{3}{*}{ Male } & \multicolumn{2}{|c|}{13} & 1 & \multicolumn{2}{|c|}{$13(35.14)$} \\
\hline & \multicolumn{2}{|l|}{4} & 2 & \multicolumn{2}{|c|}{$8(21.62)$} \\
\hline & \multicolumn{2}{|l|}{1} & 3 & \multicolumn{2}{|c|}{$3(8.11)$} \\
\hline Subtotal & \multicolumn{2}{|l|}{17} & 6 & \multicolumn{2}{|c|}{$24(64.87)$} \\
\hline \multirow{2}{*}{ Female } & \multicolumn{2}{|l|}{9} & 1 & \multicolumn{2}{|c|}{$9(24.32)$} \\
\hline & \multicolumn{2}{|l|}{2} & 2 & \multicolumn{2}{|c|}{$4(10.81)$} \\
\hline Subtotal & \multicolumn{2}{|l|}{11} & 3 & \multicolumn{2}{|c|}{$13(35.13)$} \\
\hline Total & \multicolumn{2}{|l|}{28} & 9 & \multicolumn{2}{|c|}{$37(100)$} \\
\hline Category & \multicolumn{2}{|l|}{ Types of NOM } & $n=37$ & \multicolumn{2}{|c|}{ Percentage $(\%)$} \\
\hline \multirow{2}{*}{ Necessity } & \multicolumn{2}{|l|}{ Untreated health problem } & 5 & 13.5 & \\
\hline & Effect of unnecessary me & & - & - & \\
\hline Fffectiveness & Quantitative ineffectiven & & 5 & 13.5 & \\
\hline EHectiventess & Non-quantitative ineffect & & 4 & 11 & \\
\hline Safety & Quantitative safety proble & & - & - & \\
\hline sarety & Non-quantitative safety $p$ & & 23 & 62 & \\
\hline Total & & & 37 & 100 & \\
\hline
\end{tabular}

Table 3 Types of DRP (drug-related problems) by severity of safety problems.

\begin{tabular}{lllllll}
\hline \multirow{2}{*}{ NOM } & Severity & \multicolumn{3}{c}{ Male } & \multicolumn{2}{c}{ Female } \\
\cline { 3 - 7 } & $n=23$ & Number & Percentage (\%) & Number & Percentage (\%) & Total \\
\hline NQSP & Moderate & 7 & 30.43 & 7 & 30.43 & 60.86 \\
NQSP & Severe & 5 & 21.74 & - & - & 21.74 \\
NQSP & Mild & 3 & 13.04 & 1 & 4.35 & 17.39 \\
Total & & 15 & 65.21 & 8 & 34.78 & 100.00 \\
\multicolumn{2}{l}{ Correlation coefficient $r=-0.34$} & & & & & \\
\hline
\end{tabular}

NQSP: non-quantitative safety problem;

Source: data obtained during drug therapy monitoring process. 
Table 4 Number of drugs prescribed to patients with DM2 and HTN, and therapeutic groups affected.

\begin{tabular}{|c|c|c|c|c|}
\hline No. of drugs prescribed per patient & \multicolumn{2}{|c|}{ No. of patients $(n=29)$} & Total drugs prescribed $(n=204)$ & Percentage $(\%)$ \\
\hline 8 & \multicolumn{2}{|c|}{8} & 64 & 31 \\
\hline 7 & \multicolumn{2}{|l|}{5} & 35 & 17 \\
\hline 11 & \multicolumn{2}{|l|}{3} & 33 & 16 \\
\hline 9 & \multicolumn{2}{|l|}{3} & 27 & 13 \\
\hline 6 & \multicolumn{2}{|l|}{4} & 24 & 12 \\
\hline 4 & \multicolumn{2}{|l|}{2} & 8 & 4 \\
\hline 3 & \multicolumn{2}{|l|}{2} & 6 & 3 \\
\hline 2 & \multicolumn{2}{|l|}{1} & 2 & 3 \\
\hline 5 & \multicolumn{2}{|l|}{1} & 5 & 2 \\
\hline 2 & \multicolumn{2}{|l|}{1} & 2 & 1 \\
\hline Total & \multicolumn{2}{|l|}{29} & 204 & 100 \\
\hline \multicolumn{5}{|l|}{ Student's $t$-test $7 \pm 0.88(6.11 \sim 7.88)$} \\
\hline Therapeutic group & Necessity & Effectiveness & Safety & Percentage $(\%)$ \\
\hline A: alimentary tract and metabolism & $-{ }^{\mathrm{a}}$ & $-^{\mathrm{a}}$ & 11 & $11(30)$ \\
\hline B: blood and blood forming organs & 5 & $\mathrm{a}^{\mathrm{a}}$ & 6 & $11(30)$ \\
\hline C: cardiovascular system & $-{ }^{a}$ & 9 & $-{ }^{\mathrm{a}}$ & $9(24)$ \\
\hline $\mathrm{N}$ : central nervous system & $-{ }^{\mathrm{a}}$ & $-{ }^{\mathrm{a}}$ & 4 & $4(11)$ \\
\hline D: dermatologicals & $-{ }^{\mathrm{a}}$ & $-^{\mathrm{a}}$ & 1 & $1(2.5)$ \\
\hline M: musculoskeletal system & $-^{\mathrm{a}}$ & $-^{\mathrm{a}}$ & 1 & $1(2.5)$ \\
\hline Total & 5 & 9 & 23 & $37(100)$ \\
\hline
\end{tabular}

$-^{\mathrm{a}}:$ not reported; Based on ATC classification [33].

Source: data obtained during drug therapy monitoring process. 
Table 5 Prescribed drugs involved in the appearance of NOM (negative outcomes associated with medication) in patients with DM2 and HTN.

\begin{tabular}{|c|c|c|c|c|c|c|c|c|c|c|}
\hline \multirow{2}{*}{\multicolumn{2}{|c|}{ Drug involved in the NOM }} & \multicolumn{3}{|c|}{ Necessity } & \multicolumn{2}{|c|}{ Effectiveness } & \multicolumn{2}{|c|}{ Safety } & \multirow{2}{*}{\multicolumn{2}{|c|}{$\begin{array}{l}\text { Total } \\
\mathrm{n}=37(\%)\end{array}$}} \\
\hline & & $\begin{array}{l}\text { UHP } \\
n=0\end{array}$ & & $\begin{array}{l}\text { EUM } \\
n=0\end{array}$ & $\begin{array}{l}\text { QI } \\
n=8\end{array}$ & $\begin{array}{l}\text { NQI } \\
n=7 \\
\end{array}$ & $\begin{array}{l}\text { QSP } \\
n=0\end{array}$ & $\begin{array}{l}\text { NQSP } \\
n=22\end{array}$ & & \\
\hline \multicolumn{2}{|l|}{ Losartan } & $-{ }^{\mathrm{a}}$ & \multicolumn{2}{|l|}{$-^{\mathrm{a}}$} & 5 & & $-^{\mathrm{a}}$ & 2 & \multicolumn{2}{|l|}{$10(27)$} \\
\hline \multicolumn{2}{|l|}{ Furosemide } & $-^{\mathrm{a}}$ & \multicolumn{2}{|l|}{$-^{\mathrm{a}}$} & $-^{a}$ & $-^{a}$ & $-^{\mathrm{a}}$ & 7 & \multicolumn{2}{|l|}{$7(19)$} \\
\hline \multicolumn{2}{|l|}{ Amlodipine } & $-^{\mathrm{a}}$ & \multicolumn{2}{|l|}{$-^{\mathrm{a}}$} & 3 & 2 & $-^{\mathrm{a}}$ & 1 & \multicolumn{2}{|l|}{$6(16)$} \\
\hline \multicolumn{2}{|l|}{ Metoprolol } & $-^{\mathrm{a}}$ & \multicolumn{2}{|l|}{$-^{\mathrm{a}}$} & $-^{a}$ & 1 & $-{ }^{\mathrm{a}}$ & 4 & \multicolumn{2}{|l|}{$5(14)$} \\
\hline \multicolumn{2}{|l|}{ Omeprazole } & $-^{\mathrm{a}}$ & \multicolumn{2}{|l|}{$-^{\mathrm{a}}$} & $-^{a}$ & $-^{a}$ & $-^{\mathrm{a}}$ & 2 & \multicolumn{2}{|l|}{$2(5.41)$} \\
\hline \multicolumn{2}{|l|}{ Atorvastatin } & $-^{\mathrm{a}}$ & \multicolumn{2}{|l|}{$-^{a}$} & $-^{a}$ & $-^{a}$ & $-^{\mathrm{a}}$ & 1 & \multicolumn{2}{|l|}{$1(2.70)$} \\
\hline \multicolumn{2}{|l|}{ Clopidogrel } & $-^{\mathrm{a}}$ & $-^{a}$ & & $-^{a}$ & $-^{\mathrm{a}}$ & $-^{\mathrm{a}}$ & 1 & $1(2.70)$ & \\
\hline Isosorbide dini & itrate & $-^{\mathrm{a}}$ & $-^{\mathrm{a}}$ & & $-^{\mathrm{a}}$ & ${ }^{\mathrm{a}}$ & ${ }^{\mathrm{a}}$ & 1 & $1(2.70)$ & \\
\hline Metformin & & $-^{\mathrm{a}}$ & $-^{\mathrm{a}}$ & & $-^{\mathrm{a}}$ & $-^{\mathrm{a}}$ & $-^{\mathrm{a}}$ & 1 & $1(2.70)$ & \\
\hline Sucralfate & & $-^{\mathrm{a}}$ & $-^{\mathrm{a}}$ & & $-^{a}$ & $-^{\mathrm{a}}$ & $-^{\mathrm{a}}$ & 1 & $1(2.70)$ & \\
\hline Vancomycin & & $-{ }^{\mathrm{a}}$ & $-^{a}$ & & $-^{\mathrm{a}}$ & $-{ }^{\mathrm{a}}$ & $-{ }^{\mathrm{a}}$ & 1 & $1(2.70)$ & \\
\hline Enalapril & & $-^{\mathrm{a}}$ & $-^{\mathrm{a}}$ & & $-^{\mathrm{a}}$ & 1 & $-^{\mathrm{a}}$ & $-^{\mathrm{a}}$ & $1(2.70)$ & \\
\hline Total & & $-^{\mathrm{a}}$ & $-^{\mathrm{a}}$ & & 8 & 7 & $-^{\mathrm{a}}$ & 22 & $37(100)$ & \\
\hline Category & Type of NOM & & $\begin{array}{l}\text { No. NOM in patients } \\
\text { with DM } 2 \text { and HTN } n \\
=18\end{array}$ & $\begin{array}{l}\text { Percenta } \\
\text { in patier } \\
\text { HTN }\end{array}$ & $\begin{array}{l}(\%) \text { of NOM } \\
\text { with DM2 and }\end{array}$ & $\begin{array}{l}\text { No. NOM in } \\
\text { patients with DM2 } \\
n=2\end{array}$ & $\begin{array}{l}\text { Percentage }(\%) \\
\text { of NOM in } \\
\text { patients with } \\
\text { DM2 }\end{array}$ & $\begin{array}{l}\text { No. NOM in patients } \\
\text { with HTN } n=17\end{array}$ & $\begin{array}{l}\text { Percentage } \\
(\%) \text { of NOM } \\
\text { in patients } \\
\text { with HTN }\end{array}$ & Total \\
\hline & Untreated health prob & lem & 3 & 8.11 & & $-^{a}$ & $-^{\mathrm{a}}$ & 2 & 5.41 & 13.52 \\
\hline Necessity & $\begin{array}{l}\text { Effect of unnecessary } \\
\text { medicine }\end{array}$ & & $-^{a}$ & $-^{\mathrm{a}}$ & & $-^{a}$ & $-^{\mathrm{a}}$ & $\mathrm{-}^{\mathrm{a}}$ & $-^{\mathrm{a}}$ & - $^{\mathrm{a}}$ \\
\hline & Quantitative ineffectiv & veness & 1 & 2.70 & & 1 & 2.70 & 3 & 8.11 & 13.51 \\
\hline Effectiveness & $\begin{array}{l}\text { Non-quantitative } \\
\text { ineffectiveness }\end{array}$ & & 3 & 8.11 & & $-^{\mathrm{a}}$ & $-^{\mathrm{a}}$ & 1 & 2.70 & 10.81 \\
\hline & Quantitative safety pr & oblem & $-^{\mathrm{a}}$ & $-{ }^{\mathrm{a}}$ & & $-^{\mathrm{a}}$ & $-^{\mathrm{a}}$ & $-^{\mathrm{a}}$ & $-^{\mathrm{a}}$ & $-^{\mathrm{a}}$ \\
\hline Safety & $\begin{array}{l}\text { Non-quantitative safe } \\
\text { problem }\end{array}$ & & 11 & 29.73 & & 1 & 2.70 & 11 & 29.73 & 62.16 \\
\hline Total & & & 18 & 48.65 & & 2 & 5.40 & 17 & 45.95 & 100 \\
\hline
\end{tabular}

-a: not reported; UHP: untreated health problem; EUM: effect of unnecessary medicine; QI: quantitative ineffectiveness; NQI: non-quantitative ineffectiveness; QSP: quantitative safety problem; NQSP: non-quantitative safety problem.

Source: data obtained during drug therapy monitoring process 
Table 6 Outcomes of pharmacist interventions sent to doctors, nurses and patients, and avoidability of negative outcomes associated with medication.

\begin{tabular}{|c|c|c|c|c|c|c|c|c|}
\hline \multirow[b]{2}{*}{$\begin{array}{l}\text { Pharmacist interventions } n= \\
35\end{array}$} & \multicolumn{4}{|c|}{ Method of communication } & \multicolumn{4}{|c|}{ Health problem } \\
\hline & $\begin{array}{l}\text { Orally and/or } \\
\text { in writing to } \\
\text { doctor }\end{array}$ & $\begin{array}{l}\text { Orally and/or in } \\
\text { writing to } \\
\text { caregiver }\end{array}$ & $\begin{array}{l}\text { Number of patients } \\
\text { with interventions } \\
n=35\end{array}$ & $\begin{array}{l}\text { Percentage } \\
(\%) \text { of } \\
\text { patients with } \\
\text { interventions }\end{array}$ & $\begin{array}{l}\text { No. of patients } \\
\text { with HP } \\
\text { resolved }\end{array}$ & $\begin{array}{l}\text { Percentage }(\%) \text { of } \\
\text { patients with } \\
\text { interventions } \\
\text { whose HP were } \\
\text { resolved }\end{array}$ & $\begin{array}{l}\text { No. of patients } \\
\text { with unresolved } \\
\text { HP }\end{array}$ & $\begin{array}{l}\text { Percentage }(\%) \text { of } \\
\text { patients with } \\
\text { interventions whose } \\
\text { HP were not resolved }\end{array}$ \\
\hline \multicolumn{9}{|l|}{ Pharmacist patient doctor } \\
\hline $\begin{array}{l}\text { Accepted without } \\
\text { modification }\end{array}$ & $23(65.71)$ & $1(2.86)$ & 24 & 68.57 & 17 & 48.57 & 7 & 20.00 \\
\hline $\begin{array}{l}\text { Rejected by the doctor with } \\
\text { reasons }\end{array}$ & 5 & 0 & 5 & 14.29 & 3 & 8.57 & 2 & 5.71 \\
\hline $\begin{array}{l}\text { Rejected by the doctor } \\
\text { without reasons }\end{array}$ & 6 & 0 & 6 & 17.14 & 4 & 11.43 & 2 & 5.71 \\
\hline Subtotal & 34 & 1 & 35 & 100 & 24 & 68.57 & 11 & 31.42 \\
\hline \multicolumn{9}{|c|}{$\begin{array}{l}\text { Interventions accepted: } 24 \text { (68.57) } \\
\text { Interventions not accepted: } 11(31.43 \%)\end{array}$} \\
\hline Avoidability of NOM & & & $n=35$ & Percentage ( $\%$ & & & & \\
\hline Not avoidable & & & 25 & 71.43 & & & & \\
\hline Avoidable & & & 10 & 28.57 & & & & \\
\hline
\end{tabular}

Total

Source: data obtained from the pharmacist intervention sheet. 


\section{Discussion}

This drug therapy monitoring study consisted of three stages: the detection, analysis and resolution of DRP and NOM linked to DM2 and HTN, both causes of cardiovascular and renovascular disease. The sample group consisted of more men (54.79\%) than women, unlike that of the study by Pérez [17], who reported a higher percentage of women. Most of the participants were 60 years of age or older $(68.5 \%)$. It could be inferred that DM2 risk factors increase with age, as insulin secretion decreases at a rate of approximately $0.7 \%$ per year [18].

The most prevalent diagnosis was HTN only (58.90\%), followed by DM2 with HTN (35.62\%) and DM2 only $(5.48 \%)$. The efficacy of the doctor-pharmacist collaboration studied is consistent with the findings of previous studies on the role of pharmacists in the treatment of DM2, HTN [19-22] and metabolic syndrome [23]. The results of this study are also consistent with others on the monitoring of HTN [24], DM2 [25] or HTN and DM2.

A simple linear correlation analysis was used to determine the strength of linear association between the variables studied. The correlation coefficient calculated was -0.34 , indicating a weak association between patient age and NOM severity. A negative coefficient also indicates an inverse relationship between these variables. The interval estimate for the number of drugs that caused NOM was $6 \sim 8$, with a $95 \%$ confidence interval. This shows that a higher number of prescribed drugs is not directly linked to the number of patients with NOM.

The DTM service detected 35 suspected NOM. A similar study by Marcel [26] detected 89 NOM, confirming the need to implement DTM programs in high-risk patient groups.

Pharmacist interventions were conducted in just $47.95 \%$ of the 73 patients included in the sample group. $68.57 \%$ of the 35 pharmacist interventions were accepted and $31.43 \%$ were not accepted, showing a high level of acceptance of the DTM service among patients and doctors. This teamwork helps to improve the clinical condition of chronic patients such as diabetics, as found in previous studies [27-29].

Of the 35 NOM detected, $71.43 \%$ were unavoidable and $28.57 \%$ were avoidable. Studies in both outpatient [30] and hospital settings have shown that most NOM detected could be avoided, up to $70 \%$ in some cases [31, 32]. Through opportune interventions, NOM could be avoided altogether [33].

\section{Conclusions}

Pharmacotherapeutic follow-up is a professional service that improves the care of diabetic patients with hypertension. It was identified that men predominate with these pathologies, with an age greater than 60 years. Pharmaceutical interventions were used as a solution strategy for NOM, where medical and pharmaceutical professionals were involved. Identifying 35 suspicions of NOM, which reached a high level of acceptance of the drug therapy monitoring process service in patients and medicals. Being avoidable the $28.57 \%$ in the hospital environment.

\section{Conflict of interest}

The authors declare that there is no conflict of interest regarding the publication of this paper. This study is part of José Francisco Castro Bolívar's doctoral thesis and the doctorate program of the University of Granada.

\section{References}

[1] Barahona, N. I., and Andino, G. 2007. "Application of the Dader Method of Pharmaceutical Care in Outpatient Diabetic Patients of the IESS General Hospital. Riobamba." To opt for the title Doctor Bioquimica y Farmacia, Escuela Superior Politecnica de Chimborazo.

[2] Machuca, F. M., Fernández-Llimós, M. F., Faus, M. J. 2003. Método Dáder: Guía De Seguimiento Farmacoterapéutico. Grupo De Investigación en Atención Farmacéutica (CTS-131). Universidad de Granada. Accessed October $\quad 10, \quad 2016$. www.cipf-es.org/files/doc004.pdf. 
[3] Wild, S., Roglic, G., Green, A., Sicree, R., and King, H. 2004. "Global Prevalence of Diabetes: Estimates for the Year 2000 and Projections for 2030." Diabetes Care 27 (5): 1047-53.

[4] World Health Organization. 2014. Global Status Report on Noncommunicable Diseases 2014. Geneva: World Health Organization.

[5] WHO (World Health Organization). 2014. Global Health Estimates: Deaths by Cause, Age, Sex and Country, 2000-2012. Geneva: WHO.

[6] Mathers, C. D., and Loncar, D. 2006. "Projections of Global Mortality and Burden of Disease from 2002 to 2030." PLoS Med. 3 (11): e442.

[7] WHO (World Health Organization). 2011. Global Status Report on Noncommunicable Diseases 2010. Geneva: World Health Organization.

[8] Centro Andaluz de Información de Medicamentos. 2004. "Papel de las tiazolidonas en el tratamiento de la DM2: Puesta al día." Escuela Andaluza de Salud Pública 20 (4): 13-4.

[9] Melchiors, A. C., Correr, C. J., Rossignoli, P. S., Pontarolo, R., and Fernández-Llimós, F. 2004. "Medidas de Evaluación de la Calidad de Vida en Diabetes." Pharmacy Practice 2 (1): 1-11.

[10] Orozco, A. M. 2004. "Hipertensión Arterial y Diabetes Mellitus." Rev Costarric Cienc Méd 25: 65-71.

[11] García Castillo, E., De Haro Pérez, E. M., and López Castellanos, A. C. 2008. "Implantación de un Programa de Educación Sanitaria y Seguimiento Farmacoterapéutico a Pacientes con Diabetes Tipo 2 en una Farmacia Comunitaria." Rev OFIL 18 (3): 43-54.

[12] Toledano, C., Ávila, L., and García, S. 2012. "Seguimiento Farmacoterapéutico en una Población Ambulatoria con Diabetes Mellitus Tipo 2." Rev Mex Cienc Farm. 43 (2): 54-60.

[13] WMA (World Medical Association). 1975. World Medical Association Declaration of Helsinki. Tokyo: WMA.

[14] Comité de Consenso. 2007. "Tercer Consenso de Granada Sobre Problemas Relacionados con los Medicamentos PRM y Resultados Negativos Asociados a la Medicación RNM." Arspharm. 48: 5-17.

[15] Naranjo, C. A., Busto, U., Sellers, E. M., Sandor, P., Ruiz, I., Roberts, E. A., et al. 1981. "A Method for Estimating the Probability of Adverse Drug Reactions." Clin Pharmacol Ther 30 (2): 239-45

[16] Frick, P., Cohen, L., and Rovers, J. 1997. "Algorithms Used in Adverse Drug Event Reports: A Comparative Study." Ann Pharmacothe 31 (2): 164-7.

[17] Pérez Ballester, T., González Pérez, R., Rius Chávez, C., and Martín Calero, M. J. 2004. "Incidencia del Seguimiento Farmacoterapéutico en Pacientes Diabéticos." Seguim Farmacoter 2 (4): 228-34.
[18] Szoke, E., Shrayyef, M. Z., Messing, S., Woerle, H. J., Van Haeften, T. W., Meyer, C., et al. 2008. "Effect of Aging on Glucose Homeostasis." Diabetes Care 31: 539-43.

[19] Ramser, K. L., Sprabery, L. R., George, C. M., Hamann, G. L., Vallejo, V. A., Dorko, C. S., et al. 2008. "Physician-Pharmacist Collaboration in the Management of Patients with Diabetes Resistant to Usual Care." Diabetes Spect 21 (3): 209-14.

[20] Carter, B. L., Ardery, G. Dawson, J. D., James, P. A., Bergus, G. R., Doucette, W. R., et al. 2009. "Physician and Pharmacist Collaboration to Improve Blood Pressure Control." Arch Intern Med 169 (21): 1996-2002.

[21] Kelly, C. J. G. 2008. "Booth G. Pharmacist-Led Structured Care for Patients with Diabetic Nephropathy." Br J Diabetes Vasc Dis 8 (2): 86-8.

[22] Mclean, D. L., Mcalister, F. A., Johnson, J. A., King, K. M., Makowsky, M. J., Jones, C. A., et al. 2008. “A Randomized Trial of the Effect of Community Pharmacist and Nurse Care on Improving Blood in Patients with Diabetes Mellitus: Study of Cardiovascular Risk Intervention by Pharmacists-Hypertension (SCRIP-HTN). Arch Intern Med 168 (21): 2355-61.

[23] Hammad, E. A., Yasein, N., Tahaineh, L. and Albsoulyounes, A. M. 2011. "A Randomized Controlled Trial to Assess Pharmacist-Physician Collaborative Practice in the Management of Metabolic Syndrome in a University Medical Clinic in Jordan." J Manag Care Pharm 17 (4): 295-303.

[24] Castro, M. S., Fuchs, F. D., Santos, M. C., Maximiliano, P. Gus, M., Moreira, L. B., et al. 2006. "Pharmaceutical Care Program for Patients with Uncontrolled Hypertension." Am J Hypertens 19 (5): 528-33.

[25] Correr, C. J., Melchiors, A. C., Fernandez-Llimos, F., and Pontarolo, R. 2011. "Effects of a Pharmacotherapy Follow-Up in Community Pharmacies on Type 2 Diabetes Patients in Brazil.” Int. J. Clin. Pharm. 33 (2): 273-80.

[26] Marcel, A. 2007. Implementación de un Servicio de Atención a Pacientes Diabéticos Desde una Consulta de Endocrinología. La Habana: IFAL-Universidad de La Habana.

[27] Iyer, R., Coderre, P., Mckelvey, T., Cooper, J., Berger, J., Moore, E., et al. 2010. "An Employer-Based, Pharmacist Intervention Model for Patients with Type 2 Diabetes. [MEDLINE PMID: 20133537]." Am J Health Syst Pharm. 67 (4): 312-6.

[28] Lores Delgado, D., Lazo Roblejo, Y., Zúñiga Moro, A., and Bermúdez Camps, I. B. 2011. "Seguimiento Farmacoterapéutico de Pacientes con Insuficiencia Cardiaca Congestiva Dispensarizados en la Farmacia Principal Municipal Santiago de Cuba." Pharm Care Esp. 13 (3): 114-22. 
[29] Vázquez, V., Chacón, J., Espejo, J., and Faus, M. J. 2004. "Resultados del Seguimiento Farmacoterapéutico en una Farmacia Comunitaria." Seguim Farmacoter 2 (3): 189-94.

[30] Gurwitz, J. H., Field, T. S., Harrold, L. R., Rothschild, J., Debellis, K., Seger, A. C., et al. 2003. "Incidence and Preventability of Adverse Drug Events among Older Persons in the Ambulatory Setting." JAMA 289 (9): 1107-16.

[31] Baena, M. I., Faus, M. J., Fajardo, P. C., Luque, M. F., and Sierra, F. 2006. "Medicine-Related Problems Resulting in Emergency Department Visits.” Eur J Clin Pharmacol 62:
387-93.

[32] Baena, M. I., Martin, R., Olmos, J., Fajardo, P. et al. 2002. "Nuevos Criterios para Determinar la Evitabilidad de los Resultados Negativos Asociados a la Medicación. Una Revisión Actualizada a Partir de la Experiencia con 2.558 Personas." Pharm Care Esp 4: 393-6.

[33] Bränd Persson, K., and Strøm, H. 2002. "The Anatomical Therapeutic Chemical (ATC) Classification and Its Use in the Nordic Countries (document WHO/GPE/CAS/C/02.49)." Presented at Meeting of Heads of WHO Collaborating Centres for the Classification of Diseases, Brisbane, Australia. 